\title{
Ultrastructural Investigation of the Mycoparasitic Interaction between Stachybotrys elegans and its host Rhizoctonia solani
}

\author{
P. M. Charest* G. Taylor* and S. H. Jabaji-Hare** \\ *Université Laval, Dept. de Phytologie, Québec, QC, Canada G1K 7P4 \\ **McGill University, Dept. of Plant Science, Montreal, QC, Canada H9X 3V9
}

Stachybotrys elegans, a soil-borne fungus, has been described as a destructive mycoparasite of Rhizoctonia solani [1]. Detailed light and ultrastructural studies of $R$. solani hyphal and sclerotial cells parasitized with $S$. elegans revealed that parasitism of host cells was characterized by hyphal attachment and enhanced production of extracellular fibrillar material during contact, penetration of host cell walls and proliferation of trophic hyphae within the host cytoplasm [2].

S. elegans produces two exo- and one endo-acting chitinases when grown on chitin. We purified to homogeneity one of the exo-acting chitinases, $\beta-N$-acetylhexosaminidase, and partially characterized its physical and biochemical properties. The native enzyme has a molecular mass of $120 \mathrm{kDa}$ when determined by gel filtration, and $68 \mathrm{kDa}$ by SDS-PAGE which suggests that the protein may occur as a dimer in solution. The purified $\beta-N$-acetylhexosaminidase is most active at $\mathrm{pH} 5.0$ and at $40^{\circ} \mathrm{C}$; it hydrolyzed the $\rho N P-N$-acetyl- $\beta$-D-glucosaminide with apparent $K_{\mathrm{m}}$ of $84.6 \mu \mathrm{M}$. Polyclonal antibodies raised against the $68 \mathrm{kDa} \beta$ - $N$-acetylhexosaminidase (NAG-68) indicated that the antibody is highly specific and recognizes the protein in crude filtrate preparation (Fig. 1) [3].

Transmission electron microscopy observations of areas sampled from the interaction zone of both fungi in dual culture revealed that $S$. elegans penetrated $R$. solani thick hyphal cell walls and the cytoplasm of the host cells was in an advanced state of disintegration (Fig. 2). Interestingly, in sections sampled from areas where both fungi were in close vicinity but not in direct interaction, $R$. solani cytoplasm was highly altered (data not shown). This indicates that the mycoparasite can affect its host in advance to penetration. At penetration sites (Fig. 3), the extent of the extracellular fibrillar material surrounding S. elegans cells was often abundant. In order to demonstrate that an exo-acting chitinase of $S$. elegans is involved in the degradation process of $R$. solani, we carried out immunocytochemical investigation using the characterized antibody described here. These studies are complemented with other cytochemical tests for the localization of chitin.

\section{References}

[1] Benyagoub M. et al. 1994. Mycological Research 98:493-505.

[2] Benyagoub M. et al. 1996. Mycological Research 100:79-86.

[3] Taylor et al. 2002. Purification and characterization of an extracellular exochitinase, $\beta-N$ acetylhexosaminidase from the fungal mycoparasite Stachybotrys elegans. Can. J. Microbiol. (in press). 


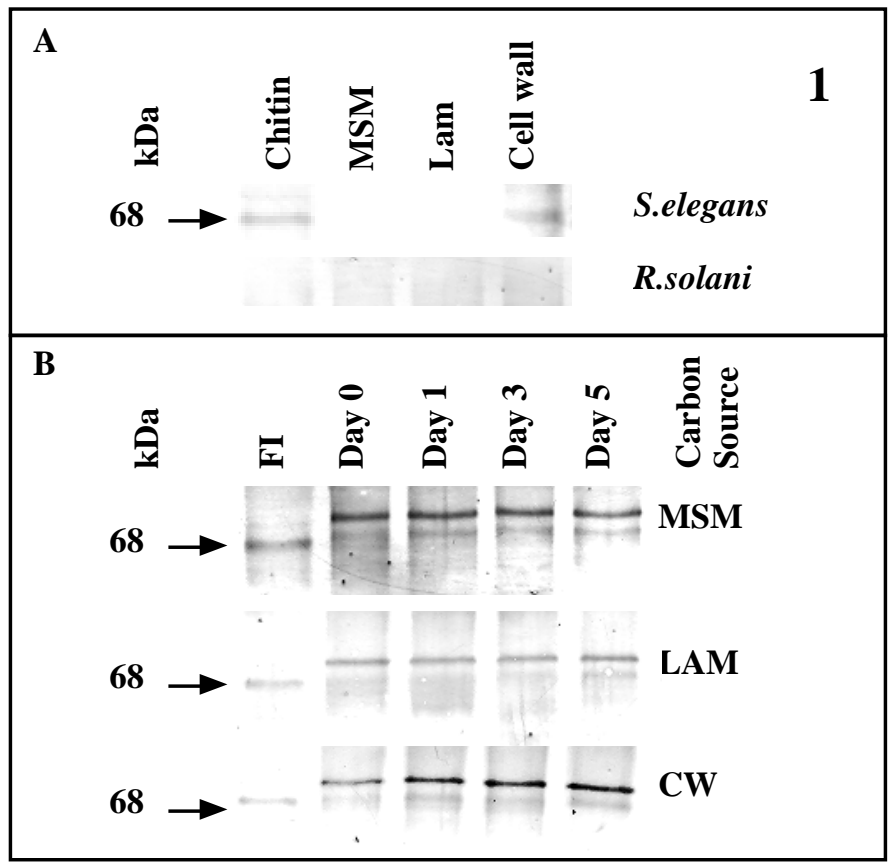

Figure 1: Western blot analysis of $S$.

elegans and $R$. solani interactions using a

polyclonal antibodies raised against the purified 68-kDa exochitinase. (A)

Intercellular proteins $(250 \mathrm{ng} / \mathrm{lane})$ extracted

from S. elegans and R. solani grown on MSM supplemented with different carbon sources $\left(0.5 \mathrm{~g} . \mathrm{L}^{-1}\right)$. Chitin (CHT), laminarin (LAM), $R$. solani cell wall fragments $(\mathrm{CW})$, or no carbon source (MSM). (B)

Intercellular proteins extracted from the interaction zone of $S$. elegans and $R$. solani in dual culture plates $0,24,72$ and $120 \mathrm{~h}$ after contact. NAG-68kDa in fraction F I (240 ng /lane )

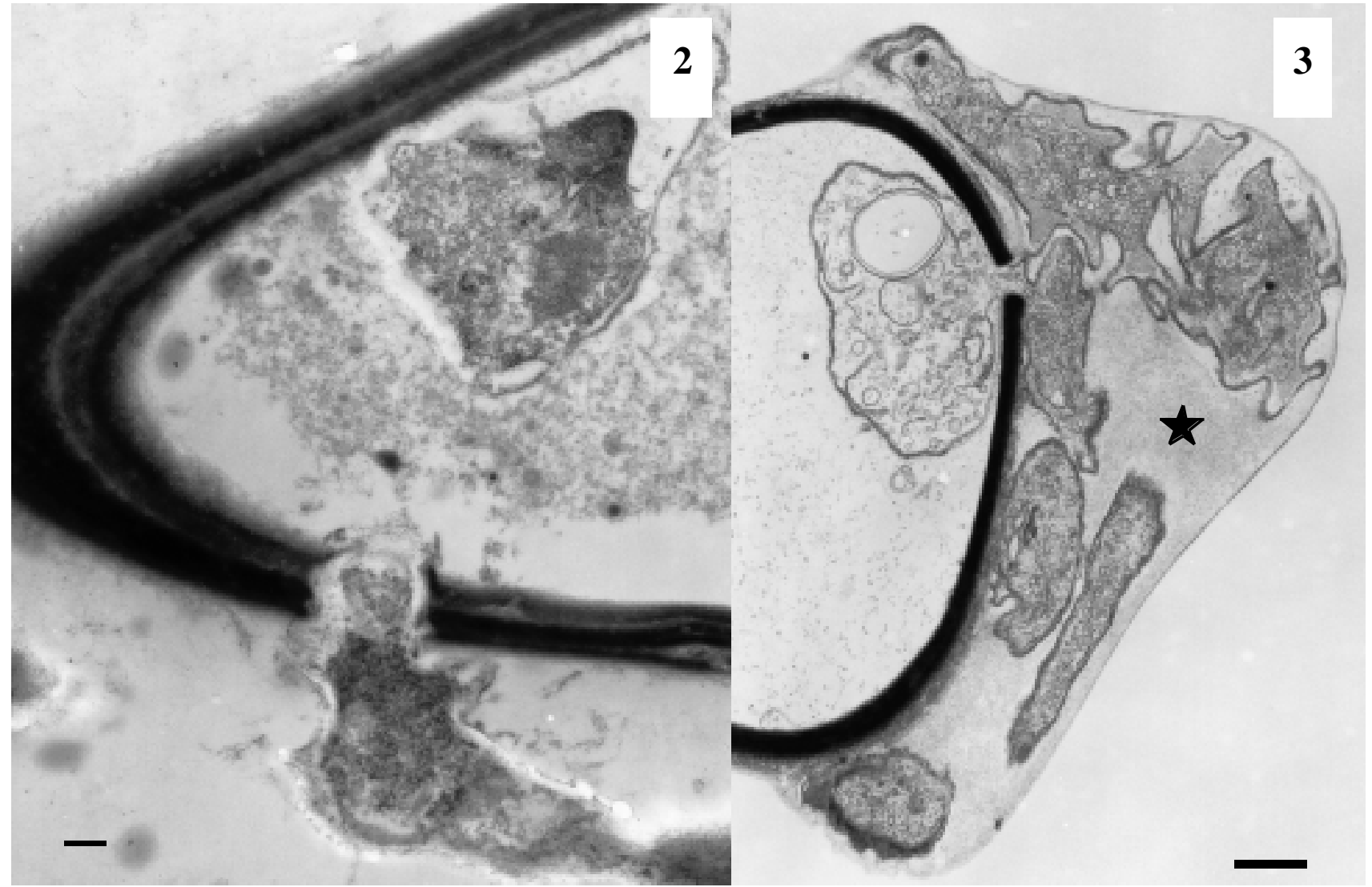

Figure 2: Penetration of $R$. solani hypha by $S$. elegans. The host cytoplasm is severely altered, no organelle is discernible. Scale bar $=500 \mathrm{~nm}$. Figure 3: Moribund hypha or $R$. solani that has been penetrated by S. elegans. The cytoplasm of the host cell is desintegrated. The S. elegans hyphae of unusual form are included in a fibrillar matrix $(*)$ outside the hypha of $R$. solani. Scale bar $=1 \mu \mathrm{m}$. 